\title{
"Det føles \\ ikke-mandigt på en måde"
}

\section{Mænd og infertilitet}

Af Tine TJørnhøJ-Thomsen

\section{Maskulinitet og evnen til at repro- ducere sig selp er tat forbundne. Holder myten om, at barnloshed er varst for kvinder og infertilitet parst for mand?}

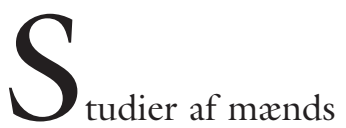
tanker, erfaringer og følelser i forbindelse med deres reproduktive liv har endnu ikke manifesteret sig på de velassorterede boghandleres hylder eller i artikeldatabaserne. Der er således ingen eller kun få fund, når man søger litteratur om mænd og reproduktion, mænd og infertilitet og lignende. Kønsstudier har primært været kvindestudier; spørgsmål om reproduktion, familie og børn har overvejende været udforsket fra kvinders perspektiv, og sammenlignet med moderskabet er det begrænset, hvad der er skrevet om faderskabets sociale, kulturelle og symbolske betydninger. Inden for det sundheds- og samfundsvidenskabelige område er der ikke produceret megen viden om det komplekse felt omkring mænds tanker, følelser og erfaringer om faderskab, reproduktion, krop og seksualitet.

Interessen for faderskabet er imidlertid øget inden for de seneste tre årtier både politisk og i forskningen. Man taler om det moderne faderskab, om ændringer i fader- 
CVELSE Nr. I8.

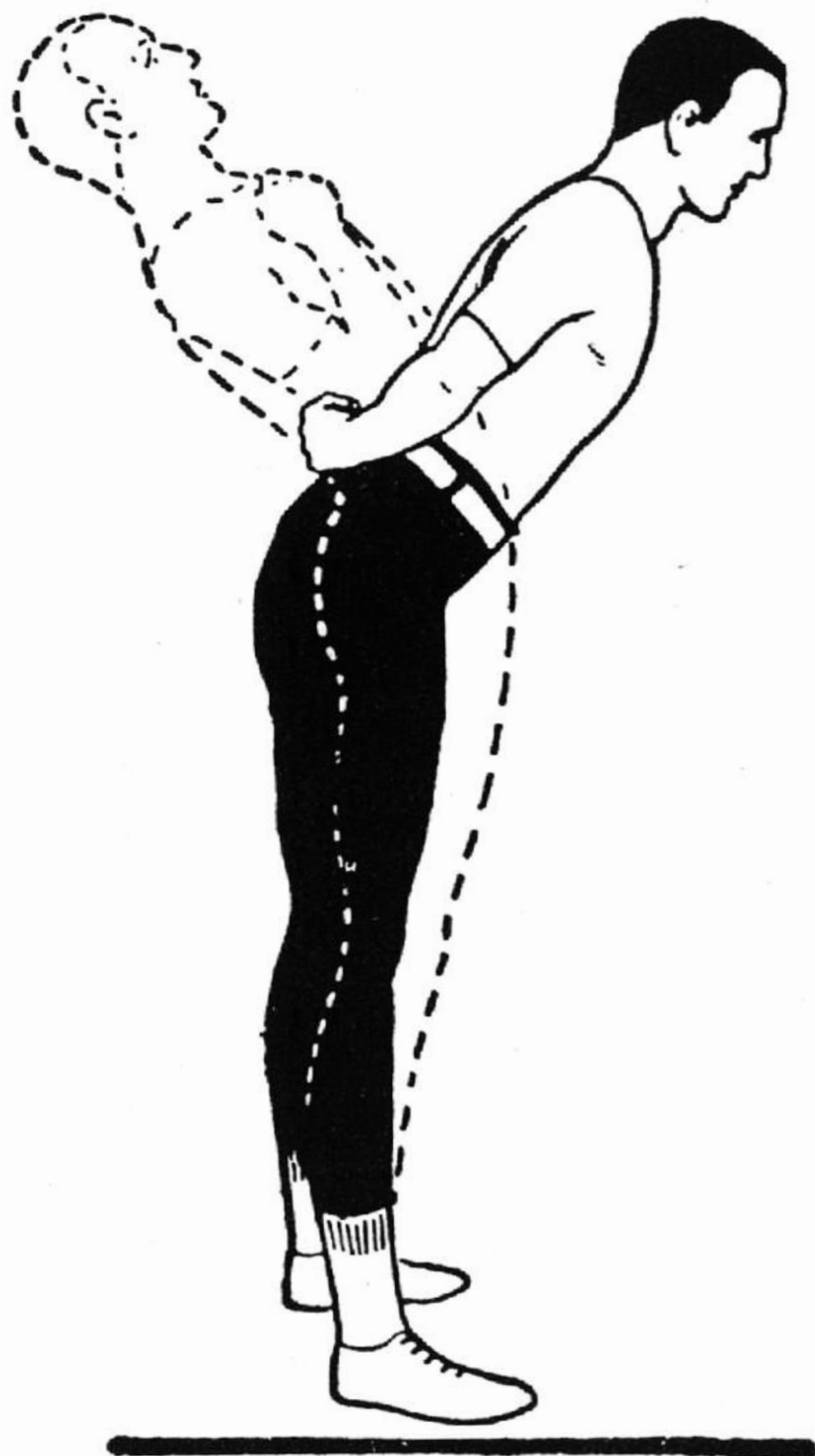

Fig. I Io. 
skabets betydninger og praksisser og diskuterer samtidig omfanget og implikationerne af disse ændringer (cf. Gillis 1992, 1996, Bergsten og Bäck-Wiklund 1996, McKeown, Ferguson, og Roony 1998, Hagström 1996, Lupton og Barcley 1997). Det moderne faderskab er, påpeges det, flertydigt og modsætningsfuldt med mange indbyggede spændinger og paradokser. De svenske forskere Birgitta Bergsten og Margareta Bäck-Wiklund (1996) refererer til en række undersøgelser, der peger på, at mænd nu er mere involveret i omsorgen for børnene og i opgaver i hjemmet, end de var tidligere, og at gængse grænser mellem moderskab og faderskab er i opbrud og til forhandling. Men undersøgelser viser også, at den kønsspecifikke arbejdsfordeling, hvad angår samvær med samt omsorg og ansvar for børnene, ikke har rykket sig markant (ibid.).

Det moderne faderskab har ikke desto mindre givet mænd mulighed for at tage del i forældreskabet på en radikalt anderledes måde end deres egne frdre (cf. Olsen 1999, Gillis 1996), og dette er, påpeger Deborah Lupton og Lesley Barclay i deres bog Constructing Fatherhood. Discourses and experiences (1997), med til at forandre traditionelle opfattelser af maskulinitet (Lupton og Barcley 1997, 1). Men faderskabet har imidlertid ikke spillet nogen hovedrolle i studier og begrebsliggørelser af maskuliniteter, hvor det indtil nu er emner som fysisk kropsudøvelse, sport, uddannelse, lønarbejde og seksuelle aktiviteter, der har været i centrum (ibid., 4).

Denne artikel beskæftiger sig med temaet "maskuliniteter" ved at belyse det relativt ubeskrevne felt, 1 der rummer mænds tanker, erfaringer og følelser i forbindelse med de aspekter af deres liv og identitet, som vedrører det at blive og at være far. Artiklen anskuer dette felt gennem en særlig optik leveret af infertile og barnløse mænd og deres partnere. Den bygger på afsnit i min ph.d-afhandling, Tilblivelseshistorier. Barnloshed, slagtskab og forplantningsteknologi $i$
Danmark (Tjørnhøj-Thomsen 1999), der i sin helhed udforsker de individuelle, sociale og kulturelle implikationer af infertilitet, ufrivillig barnløshed og brug af forplantningsteknologi. ${ }^{2}$ Artiklens empiriske afsæt er infertile og barnløse mænds og kvinders fortællinger, deres dialoger med hinanden, andre barnløse og forskeren om deres infertilitet og barnløshed og om de overvejelser, de gør sig om alternative muligheder for at få børn. Her tænker jeg på de muligheder, som forplantningsteknologien tilbyder: Det drejer sig om teknikker som donorinsemination, IVF (In Vitro Fertilisation eller reagensglasbefrugtning) og mikroinsemination. Men jeg tænker også på adoption, som er et alternativ, der også overvejes, selv om langt de fleste par i første omgang forsøger at få deres “eget" barn. ${ }^{3}$

Det er fra dette særlige perspektiv, at artiklen belyser mænds forestillinger om sig selv som fædre og del af en familie, deres og partnerens reaktioner og håndtering af deres infertilitet og barnløshed og deres forsøg på at komme overens med infertiliteten, forplantningsteknologien og måske et faderskab, der ikke forbinder dem genetisk til deres børn. Det skal understreges, at de infertile mænds tanker om - måske - at blive og være fædre ikke kun vedrører den specifikke relation til de mulige børn. Mændene refererer til kropsopfattelser, deres egen barndom og forholdet til forældre, søskende, partneren, til kolleger, venner og andre mænd. Mændene tegner således selv konturerne af forskellige relationelle og sociale kontekster, som må medtænkes i analyse, forståelse og begrebsliggørelse af deres liv. Ved for eksempel at referere til deres barndom og alderdom bringer de betydninger af generationalitet og tid på banen; og ved at referere til deres partner bringer de samtidig betydninger af køn og konjugalitet ${ }^{4} \mathrm{i}$ forgrunden. Faderskaber og maskuliniteter - som her refererer til de ideer og praksisser, der er forbundet med at blive og være far og mand - konstitueres under alle omstændigheder relationelt og kontekstuelt. 
I artiklens to første afsnit præsenteres en overordnet ramme til forståelse af de individuelle, sociale og kulturelle implikationer af infertilitet og barnløshed. De efterfølgende afsnit stiller skarpt på køn og belyser mænds tanker og følelser om deres reproduktive liv gennem en sammenligning med kvinders tilsvarende tanker og følelser. Artiklens sidste to afsnit fokuserer primært på mændenes reaktioner på og håndtering af deres dårlige sædkvalitet og infertilitet.

\section{INFERTILITET OG USIKRE LIV}

Infertilitet kan defineres som den manglende evne til at gøre eller blive gravid (cf. Lundström 1998). Infertiliteten erkendes først som et problem, når et par ønsker og forsøger at få et barn, og altså når de sociale implikationer bliver synlige (Koch 1989).

Når parret selv i ca. et år forgæeves har forsøgt at blive gravide, vil de i lægefaglig forstand være "ufrivilligt barnløse".

Fagfolk klassificerer de mange årsager til parrets ufrivillige barnløshed i tre grupper, i nogen grad afhængig af, i hvis krop årsagen til barnløsheden kan lokaliseres. Én tredjedel beror på "kvindelige faktorer", en anden tredjedel skyldes "mandlige faktorer" $o g$ for en sidste tredjedels vedkommende kan der ikke udpeges nogen egentlig årsag til parrets barnløshed, der vil være tale om uforklarlig barnløshed (Nyboe Andersen et. al. 1996). 5

Denne tredeling giver imidlertid ikke altid mening, fordi det, der forst blev defineret som årsag til parrets barnløshed, siden kan ændre sig som en følge af den nye viden, der opnås qua nye undersøgelser og behandlingsforsøg samt forskellige lægers fortolkninger heraf. At være udpeget som den infertile part afstedkommer ofte mindreværds- og skyldfølelse, og dårlig samvittighed over for partneren (og måske dennes familie) samt usikkerhed om forholdets holdbarhed (Tjørnhøj-Thomsen 1999, 107). Men hvorvidt barnløsheden beror på en mandlig eller kvindelig faktor har også andre implikationer. For der eksisterer en historisk, kulturel og institutionel betinget skrvhed i den medicinske videnskabs interesse for og følgelig viden om kvinders vis-avis mænds reproduktive liv. Andrologi er læren om sygdomme i de mandlige reproduktionsorganer (Lundström 1998, 61) og altså den mandlige pendant til det veletablerede medicinske speciale, gynækologi. Andrologi er imidlertid - forunderligt nok - ikke et godkendt medicinsk speciale (ibid.) og har derfor ikke tiltrukket yngre forskere og potentielle "vidensskabere" i samme omfang som gynækologien. Det har konsekvenser for behandlingstilbuddene til mænd og - som vi skal se - deres håndtering af infertiliteten. En fertilitetslæges bemærkning om, at de på hans klinik også er "begyndt at tage bukserne af mændene" illustrerer denne kønnede skævhed, men signalerer også den stigende interesse for andrologien inden for de seneste år. Nogle par har ikke desto mindre oplevet, at de selv måtte tage initiativ til og insistere på at få (hele) manden og ikke kun hans sæd undersøgt.

De individuelle og sociale implikationer af infertilitet og ufrivillig barnløshed 6 kan i første omgang forstås i forhold til den uorden, diskontinuitet og usikkerhed, tilstanden skaber i individuelle liv (cf. Becker 1994). En uorden, der starter med kroppen, hvis reproduktive uformåen samtidig truer forventningerne til en særlig livshistorie, karakteristisk ved en særlig livsprogression, som blandt andet refererer til forestillinger om slægtskab (se senere).

Søger vi en mere omfattende forståelse af betydningen af denne uorden, kan vi som ét muligt udgangspunkt antage, at mennesker søger at forstå de hændelser, der overgår dem ved at sætte dem ind i en tidsfølge eller et hændelsesforløb. Det vil sige, at mennesker hele tiden skaber mening med deres erfaringer, hændelser og (egne og andres) handlinger ved at organisere og udtrykke dem i en sammenhængende, tids- 
lig orden, altså give dem narrativ form. I denne proces trækker de på, motiveres af og forsøger at handle efter det repertoire af narrativer, scenarier eller diskurser, som kulturen og det sociale liv med forskellige kraft stiller til rådighed; og i samme proces både udtrykkes og formes personlig identitet. ${ }^{7}$ Identitet er således set i dette perspektiv kontekstuel og foranderlig.

For de infertile og ufrivilligt barnløse er det karakteristisk, at den livshistorie, de gerne ville leve og fortxlle - og som for eksempel handler om at blive forældre og qua moderskab og faderskab få adgang til forskellige sociale frllesskaber - ikke udfolder sig som ventet. Infertiliteten skaber et narrativt brud, der korresponderer med en identitetsmæssig desorientering. Der opstår, som det også er beskrevet i forbindelse med pludseligt opståede alvorlige sygdomme eller invaliditet (Mattingly 1998) ${ }^{8}$, et særligt behov for at bringe livet under kontrol igen, at bevare en kontinuitet trods bruddet (Becker 1994) og om muligt genoprette en alternativ orden.

Infertiliteten afstedkommer i første omgang en følelse af at være blevet snydt. Ikke kun af kroppen og naturen, men også af den udbredte idé, at reproduktion og børn - som også andre livsforhold - er og bør være resultatet af individuel kontrol, valg og ansvarlig timing (Wirtberg 1992, Lundin 1997). Mange par har sammen og hver for sig brugt prævention $\mathrm{i}$ årevis $\mathrm{i}$ forestillingen om at kontrollere, hvad der anses for at være kroppens naturlige, reproduktive potentiale. De har søgt at undgå uønsket graviditet og gjort sig overvejelser om, hvornår og med hvem de skulle have børn, samt forhandlet indbyrdes om hvilke betingelser der skulle være opfyldt, før de ville have børn. Mange lægger vægt på uddannelse, fast tilknytning til arbejdsmarkedet (det er især kvinderne) samt stabile sociale, boligmæssige og økonomiske forhold som en forudsætning for at sætte børn i verden, eller "blive klar til børn", som det udtrykkes.
Når børnene så ikke kommer som håbet, forventet eller planlagt, sker der et brud i det liv, de havde ventet at leve. Mange føler, de har mistet kontrollen med eget liv og fremtid (betydningerne af dette brud skal vi se nøjere på i næste afsnit). Samtidig kommer mange barnløse par til at leve en "hvis-nu" tilværelse, hvor de i længere perioder, også selv om de ikke ønsker det, kommer til at indrette deres liv efter graviditeten eller børnene, som måske snart kommer. De oplever at leve i et limbo med "pauseknappen trykket ind", som én formulerede denne fastholdelse i tid.

Det er det narrative brud og fastholdelsen i tid, der i første omgang forbinder infertiliteten og barnløsheden med lidelse. Infertiliteten skaber usikkerhed om fremtiden og bevirker identitetsmæssig desorientering: "Hvem skal jeg så være?" er blot et eksempel på de spørgsmål, infertiliteten rejser. De infertile både skuer tilbage i livet for at søge forklaringer på det ubegribelige og svar på spørgsmål som hvorfor mig/os og hvorfor nu, ligesom de søger at forestille sig forskellige mulige løsninger på deres barnløshed og dermed også acceptable liv(shistorier) og identiteter. Mange søger i første omgang hjælp i forplantningsteknologien. Men der opstår under alle omstændigheder et refleksions- og reformuleringsrum, hvor kulturelle værdier omkring tilblivelse, slægtskab og reproduktion, der almindeligvis tages for givet, må tages op til revision og omformuleres.

\section{INFERTILITET OG SLÆGTSKAB}

De individuelle, kulturelle og sociale implikationer af infertilitet, barnløshed og forplantningsteknologi må forstås i forhold til historisk og kulturelt betingede forestillinger om slægtskab. Et begreb, der rummer og forbinder moderskab, faderskab, forældreskab, familie og generation. Nye og anderledes familieformer genererer nye måder at være forældre på, og moderskab og faderskab tænkes, defineres og praktiseres bå- 
de i relation til hinanden og forskelligt i tid og rum (Gillis 1992, 1996 og Rosenbeck 1987). Ændringer i faderskabets betydninger er for eksempel nært forbundet med ændringer i moderskabets betingelser og vilkår (cf. McKeown, Ferguson og Roony 1998).

Den britiske antropolog Marilyn Strathern (1993) karakteriserer moderne vesteuropæisk slægtskab som en relationel kontekst, hvor slægtninge omgås med specifikke forventninger til netop slægtninges omgang med hinanden. Slægtskab betegner sociale relationer, forbundethed og samværsformer af en ganske særlig beskaffenhed og tidslig struktur. Men det, der gør slægtskabsrelationer særegne i forhold til andre sociale relationer, er, påpeger Strathern, forestillingen om slægtskabsrelationernes tilblivelse $\mathrm{i}$ den biologiske og kropslige forplantningsproces (sex, befrugtning, graviditet og fødsel) og altså slægtskabets forankring i, hvad man kunne kalde en kulturspecifik tilblivelseshistorie. En historie, der altså handler om, hvorledes personer, særlige relationer og specifikke identiteter bliver til. Det drejer sig således også om kønsidentitet, fordi det, der kulturelt konstrueres som kvindeligt og mandligt, trækker på viden om mænds og kvinders specifikke, komplementære og asymmetriske roller i reproduktionen.

Det er viden om tilblivelsens biologiske og kropslige processer, der tilfører slægtskabsrelationerne en særlig symbolsk betydning som varige og bærere af særlige følelser. Her er tillige ideer om autenticitet på spil. At blive, hvad der kulturelt og socialt anskues som "biologisk" eller "rigtig", far, mor og familie, er at blive såvel genetisk som kropsligt forbundet til et fælles barn og altså afhængig af, at kroppene hver for sig og i fællesskab formår at være både aktører og bidragydere i denne særlige tilblivelseshistorie. Den dominerende betydning, biologi og genetisk forbundethed spiller i vores samfund, finder imidlertid ikke universel udbredelse, ligesom viden om og fortolkning af tilblivelsen har ændret sig over tid. ${ }^{9}$ Barnets og forældrenes tilblivelseshistorier handler heller ikke kun om biologiske og kropslige processer. Der lægges også vægt på, som det blev nævnt i det tidligere afsnit, at barnet skal være timet, ønsket og produceret i privathed og kxrlighed og med en særlig udvalgt partner.

Den tilblivelseshistorie, de fleste gerne vil erfare og fortælle, anfægtes i første omgang af infertiliteten og ændres senere radikalt ved mødet med forplantningsteknologien. Kort fortalt bliver reproduktionen uafhængig af sex, befrugtningen uafhængig af kroppen; teknologien intervenerer i, disciplinerer og synliggør kroppen, dens substanser og forplantningsprocessen og tilføjer derved nye valg, nye erfaringer og nye måder at se og erfare krop og selv på. Eksperter og klinikpersonale (og donorer) bliver nye aktører i tilblivelsen, og gængse grænser mellem det intime, det private og det offentlige forrykkes. ${ }^{10}$

De infertiles og barnløses længsler og lidelser er komplekst forbundet med forestillinger om slægtskab og en kulturspecifik tilblivelseshistorie og vedrører både slægtskabets sociale og relationelle dimensioner og dets kropslige og biologiske aspekter. Før jeg går over til at diskutere køn i den sammenhæng, skal jeg belyse hvad, der i mere generelle termer er på spil for de barnløse mænd og kvinder, og hvad, det er for "brud", infertiliteten afstedkommer i deres liv.

De infertile og barnløse er udelukket fra at tage del i det eksklusive, daglige samvær med børn og at være en familie og skabe et hjem. Ligesom de er udelukket fra de specifikke sociale fællesskaber og ritualer, som erfaringerne $\mathrm{i}$ forbindelse med at kunne få og have børn og familieliv giver adgang til og forbinder (Tjørnhøj-Thomsen 1999, 79 ff). Disse udelukkelser får, som det senere vil fremgå, på forskellig vis konsekvenser for kompetence, selvfølelse og identitet. Men der er mere på spil, som vedrører slægtska- 
bets tidslige og generationelle dimensioner og et bestemt livsprospekt. Tanker om børn refererer ikke kun til forestillinger om fremtiden, men også fortiden. Flere peger på, at det at få børn og familie giver dem en mulighed for at genopleve, repetere og om muligt revidere egne barndomsoplevelser og egne forældres måde at være forældre på. Mange har svært ved at forestille sig at blive gamle med partneren uden børn. Børn er på den ene side et produkt af en særlig relation mellem parterne, men forventes også at tilføre relationen en ekstra dimension af frlleshed (cf. Jagd 1998) og permanens. Infertilitet og barnløshed befordrer derfor ofte spekulationer om det fremtidige liv med partneren. Mange giver udtryk for, at de qua børn kan genskabe dele af sig selv og reproducere såvel egne som partnerens egenskaber. Længslen efter at reproducere sig selv - få "egne” børn eksponeres i betydningen af "at ligne", som de fleste også har mødt i velkendte diskussioner om hvem i familien, der fysisk eller mentalt ligner hvem. Sådanne diskussioner skal ses som en symbolsk bekræftelse af familien som et genetisk fællesskab (mellem genealogiens afdøde slægtninge og de levende).

Set gennem den infertile og barnløse optik bliver det tydeligt, at det at kunne få og have børn giver adgang til sociale fællesskaber og identiteter i tid og rum. Det er at blive del af samfundet, genealogien og historien. Det tydeliggør også, at slægtskabsrelationerne er integreret $\mathrm{i}$ og forbinder andre sociale fællesskaber.

Når de barnløse søger at indkredse, hvad de selv forstår og forventer af deres "egen" familie (og her refererer de især til forældre, bedsteforældre og søskende), taler de om den, som "noget man har, uanset hvad", "familien vil altid være der", og "familien er der, hvor du kan være dig selv". Også fra dette perspektiv repræsenteres slægtskabsrelationer som varige og permanente. De barnløses egne oplevelser af familien og udvalgte familiemedlemmers re- aktion på deres situation får i nogen grad dette billede til at krakelere. De demonstrerer, at forventninger til familien, hvorledes de indfries og den særlige forbundethed, der forestilles at eksistere mellem slægtninge, uvægerligt medieres af forestillinger om køns- og generationsforskelle og individuelle præferencer (Tjørnhøj-Thomsen 1999, 105ff). For eksempel forventer mange barnløse (især kvinderne) en særlig lydhørhed og omsorg fra deres egen mor eller søster, mens de ikke nærer samme forventninger til en far eller bror.

\section{KØN SOM EN FORSKEL, DER GØR EN FORSKEL}

I infertile og barnløse mænds og kvinders fortællinger og dialoger om deres situation refererer de bestandigt til køn som en forskel, der gør en forskel. De sammenligner og generaliserer forskelle mellem mænds og kvinders oplevelser af og håndtering af infertilitet, barnløshed og møde med forplantningsteknologien. De refererer til køn i deres måde at markere, strukturere og give mening til specifikke erfaringer og praksisser på. De eksponerer derved også kulturelle forestillinger om kønsforskelle, kønnenes væsen og kønnede erfaringer. Nedenfor og i de efterfølgende afsnit skal vi se nøjere på, hvorledes køn er en forskel, der gør en forskel. Men som det vil fremgå medieres kønsforskelle af andre forskelle som for eksempel generations- og aldersforskelle og forskelle mellem mænd indbyrdes og mellem kvinder indbyrdes.

Køn træder for eksempel i forgrunden som tema, når vi går tæet på omverdenens forholden sig til ufrivillig barnløshed og forplantningsteknologien, som det kom til udtryk i den offentlige og politiske debat om kunstig befrugtning i 1995, 1996 og 1997.11 Et interessant eksempel var spørgsmålet om, hvorvidt der skulle være en fast aldersgrænse på 40 år for kvinder, når det gjaldt adgang til kunstig befrugtning. Der var mange andre udspil i den debat, så som 
hensynet til børnene og spørgsmålet om xldre førstegangsforældres forældreevne. Mest opstandelse gav det dog, da den daværende sundhedsminister foreslog en aldersgrænse for mænd på 45 år. Stemmer mod dette forslag pegede på, at mænds sædceller i modsætning til kvinders æa ikke blev dårligere med alderen. Den ældre mor forekom fra det perspektiv mere unaturlig end den $x$ ldre far. Flere ældre fædre til småbørn stod frem i medierne og tilkendegav, at de nu i fremskreden alder følte sig mere modne og parate til faderskabet (Tjørnhøj-Thomsen 1999, 76). Køn og alder blev således spundet sammen i spørgsmål om moderskabs- og faderskabsevner. Som det også blev nævnt i introduktionen, er såvel udvikling som implementering af forplantningsteknologien en kønnet affære.

\section{KØNNET ÅBENHED}

Der hersker en udbredt forestilling om, at det er godt at være "åben" om sin infertilitet og barnløshed. Denne fokusering på betydningen af åbenhed peger ikke desto mindre på, at den faktisk er svær for mange at praktisere, og at infertilitet ofte er et privat problem forbundet med skamfølelse og stilhed.

Åbenhed - det "at tale om det" især med andre i samme situation - betragtes først og fremmest som en psykisk lindring. En mand påpegede fordelen ved åbenhed således: "Det kan godt være, det lyder mærkeligt, men det er en trøst at vide, at andre har det sådan”. Hertil kommer, at fortielse og hemmelighedskræmmeri betragtes som skadeligt for sociale relationer især til familie og venner. Der kan i den forbindelse trækkes paralleller til Michel Foucaults "confessing society". Her beskriver han, hvorledes "bekendelsen" - en verbaliseret vedkendelse af tanker og handlinger er kommet til at spille en rolle i mange former for menneskelige relationer $\mathrm{i}$ vestlige samfund. Bekendelse udfolder sig altid i en særlig (magt)relation mellem den, der be- kender, og den, der straffer eller tilgiver. Til bekendelsen er også knyttet både frigørelse og lindring (Foucault 1980).

Mange føler da også en lettelse ved at få fortalt især familien om deres særlige situation. Ikke mindst fordi familien - især de potentielle bedsteforældre - spørger til børn. Åbenheden er imidlertid selektiv på flere måder. Den gxlder ikke alle i omgangskredsen i lige stort omfang, og det er heller ikke alle aspekter af infertiliteten og behandlingen, de barnløse drøfter med venner og familiemedlemmer. Hertil kommer, at mænd og kvinder håndterer det "at tale om det”, altså åbenheden, meget forskelligt. ${ }^{12}$

Forestillinger om køn fremstår her som én selektiv mekanisme ved for eksempel at forbinde følelser, åbenhed, ansvar for familiens trivsel og interesse for reproduktive emner med især kvinder. Både mænd og kvinder tilkendegiver, at mændene (sammelignet med deres partner og kvinder mere generelt) er mere "lukkede" om deres infertilitet og barnløshed blandt venner og kolleger. De "blotter sig ikke, som kvinder gør", og de er mere "blufærdige". Der er da også en tendens til i højere grad at fortie mænds infertilitet end kvinders. Langt de fleste infertile mænd har dog fortalt nære kolleger eller venner om deres problem, uden at det derfor er blevet et tilbagevendende samtaleemne. Ovenstående markeringer af kønsforskelle betyder ikke, at mænd ikke kan give udtryk for deres følelser. Snarere, at de ikke har samme traditioner og behov som kvinder for at tale om de personlige og følelsesmæssige aspekter af deres infertilitet og barnløshed eller taler om disse på en anden måde og i et andet sprog end kvinder (Schmidt 1996, 77). Mænd kan dog have svært ved at finde ord for deres reproduktive funktioner, selv når de forsøgsvis alligevel drøfter emnet med andre mænd. En infertil mand fortalte, at han havde drøftet en tv-udsendelse om faldende sædkvalitet med nogle kolleger. Han fandt det særlig interessant, at en af hans 
kolleger ikke kunne/ville udtale ordet "sæd": "Han kunne ikke sige sæd. Det var så morsomt. Han kunne ikke sige det (men sagde) de der haletudser. Hver gang ordet sæd eller sædkvalitet kom, så stoppede han op".

\section{KØNNET BARNLØSHED - KØNNET FORÆLDRESKAB}

Der er historiske og kulturelle årsager til, at mænd ikke har haft anledning eller tradition for at udveksle og tale om deres reproduktive erfaringer. De har ikke udviklet de særlige erfaringsfællesskaber, som kvinder har bygget op om deres reproduktive liv, graviditet, fødsel og omsorgen for de spæde børn, og som kvinder stadig reproducerer i vennekredsen og blandt kolleger. Kvindefællesskaber, som de infertile og barnløse kvinder i modsætning til deres partnere igen og igen bliver konfronteret med, og som de på smertelig vis føler sig udelukket fra. Disse udelukkelser er del af forklaringen på, at barnløse kvinder i langt højere grad end deres partnere giver udtryk for tab af identitet, kompetence og selvværd.

Mænd har - endnu - ikke udviklet disse fællesskaber og sproget baseret på udveksling af reproduktive erfaringer, og de bliver derfor heller ikke konfronteret med deres barnløshed i hverdagslivet på samme bastante måde som kvinder. Mænd kan i højere grad end kvinder udelukke infertiliteten og barnløsheden fra deres sociale liv, arbejdsliv og samvær med andre mænd (cf. Wirtberg 1992). De kan "bedre gemme sig i deres arbejde", som det for eksempel lyder.

Mens de barnløse kvinder igen og igen gør sig tanker om, hvorledes de skal kombinere det reproduktive liv (fertilitetsbehandlingen og mo-derskabet, de håber på) med deres lønarbejde og derved bestandigt eksponerer spændingsrummet mellem det reproduktive og det produktive arbejde i kvinders liv (cf. Franklin 1997), bringes dette tema sjældent på bane af mændene $\mathrm{i}$ deres forestillinger om en mulig fremtid med børn. Desuden lader de fleste infertile og barnløse mænd sig ikke provokere og mærke følelsesmæssigt i samme omfang som kvinder af mødet med gravide kvinder, barnevogne og småbørn: "Det kunne være rart at fă børn, men det er ikke sådan, at jeg stopper op og synker en klump, hver gang jeg ser en gravid kvinde", som en infertil mand beskriver sin - sammenlignet med partnerens - mere nøgterne reaktion. Barnløsheden går dem - efter hvad de selv og deres partnere siger - heller ikke på på samme måde (cf. Schmidt 1996). De “tager en ting ad gangen" eller "tager tingene, som de kommer". "Det er nok sværere for min kone", eller "det er værre for kvinder" lyder budskaberne.

Ved at fokusere på deres partners afsavn og lidelser bekræfter og betoner mændene de kulturelle betydninger af moderskabet for kvinders liv og identitet. Mens deres egne afsavn og betydninger af faderskabet for deres liv har tendens til at træde i baggrunden.

Det betyder imidlertid langt fra, at de er upåvirkede af deres infertilitet eller deres barnløshed. Netop fordi de er i en situation, hvor de gerne vil have børn, men ikke umiddelbart kan få det, registrerer de med særlig opmærksomhed andres forældreskab og andre mænds faderskab. Som en mand forklarede det: "De sidste to år, hver eneste gang der kører en person forbi på en cykel, så kigger jeg faktisk efter, om der sidder en børnestol på cyklen. Og det er virkelig noget, jeg sådan fokuserer på, Nå, for søren. Han har ligegodt et barn, Hvor gammel mon han er? Hvad mon han laver, og hvad mon han er for en. Tænk, han er ligegodt far".

Citatet illustrerer, at de infertile og barnløse mænd i stigende omfang bliver konfronteret med barnløsheden, fordi mænd i tæt, kropsligt samvær og leg med deres børn er blevet mere synlige i hverdagslivet og i reklamerne. Disse mere og mere iøjnefaldende repræsentationer af de 
unge fædre sammen med deres børn og deres fællesskab med andre fædre peger mod andre dimensioner af det at være mand og nye maskuliniteter (cf. Olsen 1999). Men det er altså ikke dimensioner, som de infertile og barnløse mænd umiddelbart kan tage del i.

Selv om mænd og kvinder i mange henseender deler forestillinger og forventninger til det at blive forældre, knytter de også forskellige forventninger til forældreskabet og familielivet. Mændenes billeder af sig selv som forældre og fædre retter sig primært mod leg, fritids- og udendørsliv og tumlen med lidt større børn. De forestiller sig i modsætning til kvinder legen som et væsenligt aspekt af deres liv med børn. "Den leg, som man har med børnene, den ser jeg frem til", som en mand formulerer det. Kvinderne lægger stor vægt på at få lov at opleve graviditet, fødsel og amning. Nogle mænd fortæller, at de helt små børn (og altså andres små børn) ikke siger dem så meget, men alle mændene tager for givet, at de, ligesom de også følger med deres partner til fertilitetsudredning og -behandling, skal tage del i graviditet,

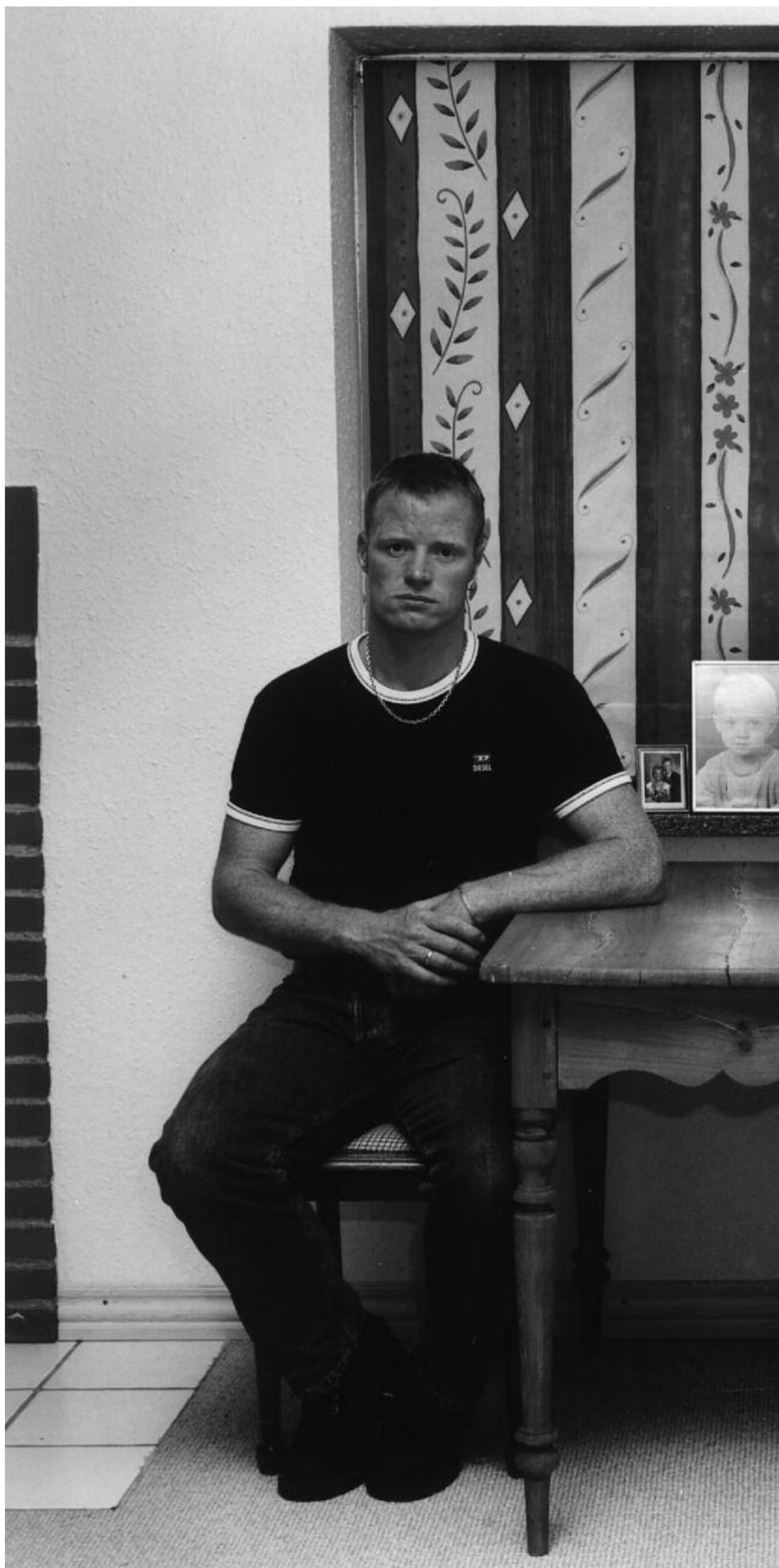




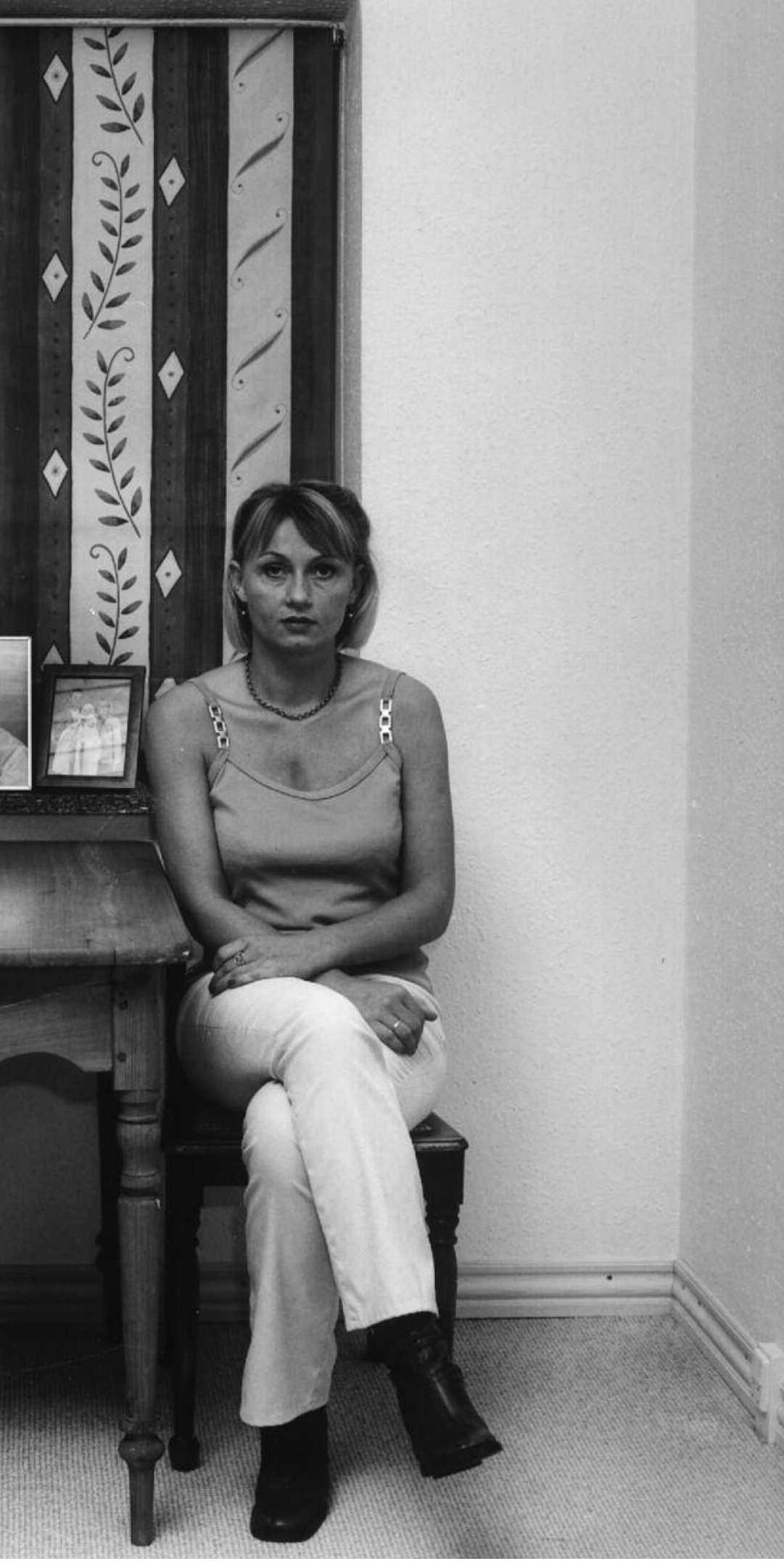

fødsel og omsorgen for det spæde barn. Nogle føler sig endog bedre rustet til dette end andre mænd, fordi de "har været så meget igennem" med deres partner i forbindelse med netop fertilitetsbehandlingen. De betragter sig derfor som mere vidende og erfarne og bedre forberedt til fødselsdramaet end andre mænd.

Enkelte mænd taler om længslen efter at "komme hjem til børn" og ønsket om børn verbaliseres iblandt som et ønske om at "få familie og skabe et hjem". En mand beskrev det således: "Det var et ønske for os begge to at få et hus med have med henblik på at få det her hjem med familie". Han forbinder dermed hjem med familie, men foretager også samtidig en distinktion mellem hus og hjem. Det er - set fra det perspektiv - børn, der gør et "hus" til en "hjem". Samme mand lægger ikke skjul på et andet afsavn: "Ligesom man kan være ensom, kan man også være tosom", som han formulerer længslen efter børn og følelsen af, at relationen til partneren mangler noget.

Hjemmet er det sted, hvor familien forventes at udfolde det særlige intime, eksklusive og nære 
samvær og de aktiviteter, der er med til at definere familien (cf. Bourdieu 1996, Olsen 1999). I bemærkningen om at "komme hjem" ser manden sig som det familiemedlem, der ikke er hjemme, men kommer hjem (til familien). Her afspejles en arbejdsdeling mellem kønnene, som stadig trænger sig på, selv om den var mere markant tidligere $\mathrm{i}$ det tyvende århundrede, hvor manden som hovedforsørger arbejdede fysisk adskilt uden for hjemmet, mens hjemmet med børnene var kvindens primære domæne (cf. Rosenbeck 1987).

De barnløse mænds længsler afspejler således et faderskab, som kombinerer forskellige elementer fra, hvad der er blevet kaldt henholdsvis det traditionelle og det moderne faderskab. De portrætterer sig i nogen grad som hovedforsørgere, lokaliseret uden for hjemmets domæne. (Det forventes, at det er kvinderne, der tager forældreorloven, hvis forældreskabet bliver en realitet). Men mændene tager også for givet, at de skal involvere sig i de mange forberedelser og ritualer, der er forbundet med graviditet og fødsel og forventer også, at de skal tage del i og bruge tid - daglig tid - på omsorg for og samvær med børnene og familien. Enkelte markerer klart, at deres faderskab skal praktiseres anderledes end deres egen fars. Der er således klare signaler om, at mændene ønsker et anderledes faderskab, der skal udfolde sig på andre måder end blot en efterligning af eller tilpasning til kvindernes moderskab (se Olsen 1999).

\section{KøN OG FERTILITETSBEHANDLING}

Når det drejer sig om at erkende og gøre noget ved barnløsheden, er det kvinderne, der tager initiativ til at opsøge læge, undersøge ventelister, tjekke de forskellige behandlingsmuligheder og opsøge alternative behandlingsformer. Det er også ofte kvinderne, der tager ordet hos lægen, stiller spørgsmål og tager initiativ til at opsøge andre barnløse (se også Schmidt 1996).
"Kvinden er bilen - manden er traileren", som en barnløs kvinde beskrev den reproduktive arbejdsdeling mellem kønnene. Det er, som kvinderne ofte understreger over for mændene, dem, der "lægger krop til" fertilitetsbehandlingen, der af mange opleves som fysisk og psykisk belastende. Derudover kan det være stressende at være i behandling, blandt andet fordi det er et stort arbejde at koordinere såvel eget som partnerens arbejdsliv og fritidsliv med undersøgelser og behandlinger. Uanset hvem der er den infertile part, skal fertilitetsbehandlingen lykkes i kvindens krop, hvis ansvar for reproduktionen fra dette perspektiv forstærkes yderligere.

Der bliver fra såvel klinikpersonalets som fra kvindernes side lagt vægt på, at manden er tilstede $\mathrm{i}$ forbindelse med behandlingen, så han kan støtte sin partner, og de kan være "fælles om det". Langt de fleste mænd i min undersøgelse (Tjørnhøj-Thomsen 1999) lægger også selv vægt på at være tilstede, selv når det ikke er egentlig påkrævet (som når de skal producere den nødvendige sædportion på klinikken): “Det er jo også mit barn", som en mand formulerede det. Ikke desto mindre føler mange mænd sig akavede og på sidelinien i klinikkens rum, hvor det er kvindekroppen, der er i centrum. De kan være bekymrede for, om de vil være i stand til at producere sædportionen, der på enkelte klinikker fordrer masturbation i et lille rum, specielt udpeget og indrettet dertil; og hvor de skal fremkalde sædafgang "på kommando" uden for den almindelige seksualitets intime og kropslige kontekst. Mændene ængstes også over, om der nu er tilstrækkelig sæd i beholderen og om sædkvaliteten, der ofte varierer meget, er god nok den aktuelle dag. Selv om mændene føler det akavet, er det vigtigt for deres selvfølelse, at de er i stand til at producere sædportionen på rette tid og sted, og at den er af tilstrækkelig volume og kvalitet. Forholdet mellem sæd og selvfølelse vender jeg tilbage til nedenfor. Mændene 
har også ofte svært ved at finde ud af, hvordan de skal støtte og trøste deres partner, hvor de skal stå, hvad de skal gøre og sige. En mand fortæller: “...men det der med bare at skulle over og aflevere den sædprøve og stille den ind i det skab og så kunne de kigge på det. Det var sådan ligesom min del af det. Og det synes jeg var rigtig mærkeligt. Også det, at min del af arbejdet med at blive far det er sådan set overtaget af lægerne. De ting, der sker, de sker mellem lægerne og min kone. På den måde står jeg udenfor, men jeg har det egentlig ikke dårlig med det, synes jeg. Jeg synes bare, det er meget forskelligt fra, hvis vi helt uproblematisk selv kunne få børn”.

På nogle klinikker forsøger man aktivt at modvirke mændenes følelse af stå på sidelinien. For eksempel ved at lade dem styre fjernbetjeningen til et tv og zappe mellem den ene kanal, der viser skanningsbilledet af kvindens æggestokke, der langsomt tømmes for $x g$, til den anden kanal, der viser laboratoriets forstørrelse af de udtagede xg.

\section{SÆD OG MASKULINITET}

Det er en chokerende erkendelse, at kroppen ikke fungerer som antaget. Ved infertilitet træder kroppen, dens organer og substanser frem fra dens almindelig ubemærkethed, som objekt for subjektet (cf. Becker 1994, Leder 1990), og den bliver derved genstand for en næsten smertefuld opmærksomhed. I forbindelse med fertilitetsbehandlingen bliver kroppens organer og substanser synlige og gjort til genstand for vurdering qua ultralydsskanninger og mikroskopi. En synlighed, der tilføjer nye historier til fortællinger om krop og selv, som vi skal se.

Dårlig og utilstrækkelig sædkvalitet er en hyppig årsag til mandlig infertilitet. Mænds infertilitet spores i første omgang gennem en analyse af deres sæd, hvor laboranten registrerer antal sædceller pr. ml. sædvæske, sædcellernes bevægelighed, svømmeevne og udseende. I laboratoriet er sæden kun en prokreativ substans, og sædkvaliteten et (om end hverken endegyldigt eller særlig godt) mål for mændenes mulighed for at blive fædre. Men for mændene er sæden samtidig også en seksuel substans, nøje forbundet med den seksuelle akt, mandens specifikke rolle $\mathrm{i}$ tilblivelseshistorien og mandlig seksualitet.

Beskeden om en dårlig sædkvalitet, og altså få, langsomme eller deforme sædceller, står uvægerligt i stærk kontrast til, hvordan sædceller beskrives i både børnebøger og udvalgt faglitteratur om emnet. Her skildres sæden som "mangfoldig", "hurtig", "aktiv" og "konkurrerende". Den heldige vinder af kapløbet, befrugteren, er i nogle tilfælde illustreret med hat, stok og knaphulsblomst, som en rigtig gentleman. Emily Martin (1991) har i en humoristisk artikel "The Egg and the Sperm" vist, hvorledes forestillinger om køn og kønsstereotyper manifesterer sig i videnskabelige beskrivelser af befrugtningen og kønscellernes natur, og hvorledes sædcellerne - sammenlignet med xgget - beskrives med maskulint ladede tillægsord, som de nævnte ovenfor. Fra dette perspektiv er der ikke meget maskulint over en dårlig sædkvalitet.

Mænd reagerer som regel i første omgang særdeles skeptisk over for beskeden om en dårlig sædkvalitet, "Det kan ikke passe", eller "der må være sket en fejl". Ønsket om at finde en forklaring på infertiliteten afstedkommer ofte selvransagelse og vrede mod kroppen og mod tidligere handlinger og levevis. I forsøget på at finde en forklaring på infertiliteten spekulerer flere mænd på, om deres infertilitet kan bero på deres mors levevis eller medicinindtag under graviditeten. Det er et emne, der også ofte har haft mediernes bevågenhed, og som er med til igen at betone kvindens reproduktive ansvar ved at gøre hendes levevis før og under graviditeten afgørende for barnets livsmuligheder. At være udpeget som den infertile part er også som nævnt 
tidligere forbundet med skyld. Mange mænd føler sig skyldige over for partneren, fordi behandlingen, også i tilfælde af mandlig infertilitet, fokuserer på kvindekroppen. En mand fortæller: "Jeg har aldrig fejlet noget, og derfor tænker man, det der med børn, det er jo ligesom alt andet, det gør man bare. Det er sådan lidt ikke-mandigt på en måde. Selv om jeg godt ved, det er noget pladder, men alligevel synes jeg ikke, jeg kan gøre de ting, som jeg gerne vil, uden at jeg skal belemre en masse andre mennesker med det. ... Der er vel nok et skjult tabu vedrørende, at man ikke er fuldt funktionsdygtig som mand; men jeg vil nok sige, at det mest var i starten. Nu har jeg affundet mig med det".

Den dårlige sædkvalitet afstedkommer følelser, der anfægter maskuliniteten ikke kun med reference til det seksuelle liv, men også som begrænsning i det individuelle råderum og en ikke ønsket afhængighed af andre.

Mange mænd bliver i denne situation på smertelig vis klar over den tidligere nævnte kønsasymmetri, der har præget den medicinske videnskabs interesse for og viden om kvinders vis-a-vis mænds reproduktive kroppe, og som afspejler sig i behandlingstilbuddene. "Som mand får du at vide, at du har nedsat sædkvalitet. Nå, så slutter historien. Man tilbyder ikke behandling, man tilbyder ingenting", som en mand udtrykker det. Som nævnt tidligere forstærker de manglende behandlingstilbud til mænd deres skyldfølelse over for partneren.

Mens adskillelsen mellem sex (seksualitet) og reproduktion i vores samfund for længst er kulturelt accepteret og nærmest påkrævet, så er seksualitet og reproduktiv formåen uadskillelig, når det kommer til den følelsesmæssige håndtering af infertiliteten.

Det, de infertile mænd er oppe imod, og det, der på et niveau befordrer følelsen af at være ikke-mandig, er, at mandlig infertilitet kulturelt associerer til impotens, tab af virilitet og til antydninger af, at infertile mænd ikke fungerer normalt seksuelt. På fornuftsplanet kan de fleste godt anfægte denne association, som manden ovenfor $\mathrm{i}$ formuleringen, "jeg ved godt, det er noget pladder, men ...". Men det forhindrer ikke, at deres følelser omkring infertiliteten fortsat er begrundet i den.

Mændenes særlige situation ansporer dem til både at reflektere over og anfæegte eller redefinere sådanne kulturelle modeller. Som den mand, der under nogen moro fortalte nogle andre barnløse, at selv om hans sædkvalitet var ekstremt ringe, så kom sæden da stadig ud med stor kraft. Underforstået at den dårlige sæd netop ikke havde noget at gøre med hans seksuelle liv og formåen.

Også kvinderne registrerer den særlige forbindelse mellem sædkvalitet, seksualitet og maskulinitet. En kvinde fortalte, at de havde undladt at fortælle en svoger om mandens dårlige sædkvalitet. En bemærkning fra svogeren om, at "ban skulle jo bare boppe på konen en gang, så var den der" gav parret forventninger om, at han, som kvinden sagde, "ville køre på, at min mand ikke er en rigtig mand og alt det der". En anden kvinde mente, at det var "heldigt", at det var hende, der var den infertile part. Hun begrundede det således: "Det er, fordi det er et eller andet med, at det er værre for en mand. Rollespillet, der er noget dér! Det er den der opfattelse, at det er jo manden, der sørger for tingene, jeg ved ikke, det er så indgroet. Det er ligesom - en mand må jo heller ikke mangle et legeme ... det er ligesom om, at mænd skal være intakte".

Det sidste udsagn drager en analogi mellem infertilitet og et ydre og mere spektakulært handicap, som i dette udsagn antages at være værre for mænd blandt andet med henvisning til begrænsningen af deres fysiske udfoldelser og forsørgerrolle.

Gennem denne optik eksponeres ideer om, at mænd - i højere grad end kvinder skal være kropsligt "funktionsdygtige", "uafhængige" og "forsørgere", ligesom dis- 
se aspekter implicit forbindes til deres reproduktiv formån og seksualitet. ${ }^{13}$ Det er interessant, at nogle partnere til infertile mænd udadtil giver indtryk af, at det er dem, der er årsagen til barnløsheden. De bryder sig ikke om at udlevere partneren og tager det på sig at beskytte ham fra bemærkninger om "mosevand i sprøjten”, og "Send hende bare hjem til mig makker". Hemmeligholdelse af mandens infertilitet kan også være et forsøg på at hemmeligholde brug af donor (se nedenfor). Mens barnløsheden beskrives som værst for kvinder, så er infertiliteten værst for mænd.

\section{EGET BARN?}

Mandlig infertilitet truer mændenes muligheder for at få eget barn og barn overhovedet. Deres mulighed for at blive genetiske forbundet til deres barn er afhængig af, hvor god sædkvaliteten er. En relativt ny teknik som mikroinsemination har gjort det muligt for mænd med meget dårlig sædkvalitet at blive genetiske fædre. ${ }^{14}$ Er sæden for dårlig også til den behandlingsform, eller vil kvinden ikke udsætte sig for den belastning, det er at være i behandling, er der mulighed for at gøre brug af sæddonor eller adoptere.

Mænds overvejelser om brug af donor giver en godt indblik i, hvad der er på spil for dem, og hvorfor det er så svært at acceptere brug af donor. De ekspliciterer, som det vil fremgå, aspekter af slægtskab og faderskab, som almindeligvis tages for givet, og viser hvor komplekst slægtskab, seksualitet og reproduktion er forbundet.

Mænds umiddelbare indvending mod brug af donor kredser for det første om relationen til partneren og en tredjeparts involvering i tilblivelseshistorien. Selv om nogle mænd bemærker, at lægen har overtaget deres arbejde, er det ikke så meget lægens rolle, som det er tanken om en fremmed mands sæd i partneren og deres egen udelukkelse af tilblivelseshistorien, der generer dem. Sxddonorens bidrag til for- plantningen associerer således til en seksuel relation til partneren - til utroskab, og det er i den forbindelse næsten umuligt ikke at forbinde sæddonorens bidrag med en person, en anden mand.

En anden invending vedrører parternes asymmetriske relation til barnet. Nogle mænd og deres partnere foretrækker umiddelbart adoption frem for brug af donor med den begrundelse, at parret så er relateret til barnet på en "lige" måde. Den ulige forbundethed til barnet, som brug af donorsæd forestilles at skabe, og som altså refererer til viden om forældrenes lige store genetiske bidrag til barnet, opfattes at skabe en ubalance i forholdet til partneren.

Endelig og for det tredje refererer den umiddelbare uvilje mod brug af donor til relationen til barnet, "For så var barnet ikke en del af mig. Simpelthen", som en mand sagde. En genetisk forbindelse associerer uvægerligt til slægtskab og altså til de følelser, forpligtelser og den varighed, som den genetiske forbundethed næsten automatisk forestilles at bære med sig. Det er derfor, at udsigten til ikke at være genetisk forbundet med barnet skaber usikkerhed om, hvorvidt det er muligt at knytte sig til barnet og om de langsigtede konsekvenser for relationen til barnet, hvis donationen bliver kendt. Langt de fleste barnløse agter i udgangspunktet at fortælle barnet om dets tilblivelse, men spekulationer om hvornår, hvordan og med hvilke konsekvenser, man skal fortælle barnet om dets tilblivelse, er særlig udtalte, når der brugt donor. I nedenstående uddrag taler manden imod insemination med donorsæd: "Altså donorsæd, det er fuldstændig udelukket, og der er ingen debat om det. Det kan jeg ikke forlige mig med. Det har jeg spekuleret over flere timer. Adoption er måske mere op til debat, men helst nej. Det, som så er så enormt svært ved det, er, at når jeg siger nej, så er diskussionen ikke længere. Og det synes jeg er enormt egoistisk over for min kone, som gerne vil have det. Jeg ville ikke kunne holde ud at gå på kompromis med 
mig selv, hvis det bliver noget halvt, det ville være det frygteligste, der kunne ske ... Det ville have katastrofale følger, hvis jeg pludselig fandt ud af, at jeg ikke kunne elske det barn, som vi havde făet".

Denne mands tanker tydeliggør endvidere, at de infertile mænds faderskab også beror på forhandlinger med og hensyn til partneren. ${ }^{15}$

Meget tyder på, at mange mænd trods deres umiddelbare modstand mod brug af donor kommer overens og efter en tid accepterer brug af donorsæd. De føler ofte, at de ikke kan tillade sig at fratage deres partner muligheden for at opleve graviditet og fødsel, for "det er noget af ypperligste, en kvinde kan opleve", som en mand formulerer det. Nogle vurderer, at fordelen ved brug af donor frem for adoption er, at parret i fællesskab vil have mulighed for at følge og drage omsorg for det ufødte barn ved muligheden for at kontrollere kvindens krop og levevis og leve op til forestillinger og krav om at være gravid på en ansvarlig måde. "Det er også vigtigt for os mænd at følge med i vores koners graviditet og fødsel og sikre, at de får lov til at opleve det", som en mand formulerede det. Da hans kone blev gravid med donor, spillede han ofte Elvis Presley for den gravide mave. Han gjorde, hvad der i højere grad nu end tidligere forventes af vordende fredre. Og netop fordi han aldrig kan blive genetisk forbundet med barnet, drager han en særlig fordel af de nye forventninger til fædre, som blev promoveret i 1960erne og ifølge Gillis, “... attempted to reconstruct rites of fatherhood that will give symbolic recognition to the expectant father and make him part of the birthing process" (Gillis 1996, 200). Selv om dette gælder alle potentielle fædre, kan man sige, at det nye faderskab giver $i$ hvert fald nogle af de infertile mænd særlige ressourcer til at (om)definere deres faderskab.

At komme overens fordrer, som nævnt, en redefinition af kulturelle værdier. Ikke mindst for, på trods af infertiliteten, at sikre en slags kontinuitet i egen livshistorie og identitet. Nogle er i stand til at acceptere brug af donor ved at "tømme" den genetiske forbindelse for associationer til seksualitet, slægtskab og arv. Deres strategi er at adskille donorens bidrag fra forestillinger om donoren som person (rival) og som forxlder. De genetiske aspekter af faderskabet nedtones til fordel for de sociale dimensioner som at "præge" barnet. Hvad der almindeligvis klassificeres som "rigtig" far, omdefineres fra at være grundfæstet i genetisk forbundethed til en forbundethed, der etableres gennem omsorg, nærhed og opdragelse af barnet. Disse mænd søger således også at omdefinere ideer om autenticitet baseret på genetiske forbundethed og oprindelse: "Jeg vil altid være barnets rigtige far", sagde en infertil mand, der havde accepteret brug af donor, ligesom han igen og igen understregede, at det, det drejer sig om, er at "præge" barnet. Efter adskillige mislykkede inseminationsforsøg med hans egen dårlige sæd, nåede denne mand frem til følgende: "Jeg er ligeglad, om jeg får mit eget barn, jeg vil bare gerne være en familie".

\section{AFsLUTNING: INFERTILITET OG AUTENTICITET}

Infertile mænds lidelser og længsler må forstås i forhold til den uorden infertiliteten skaber i deres kroppe og i forventningerne til en særlig livshistorie og identitet. En livshistorie, der trækker på historisk og kulturelt betingede forestillinger om slægtskab og køn. De barnløses længsler og lidelser reflekterer, som jeg har vist, forskellige forventninger til og betoninger af moderskabet vis a vis faderskabet. De infertile mænd har en tendens til at betone det biologiske moderskabs betydning for kvinder ved at understrege, at barnløsheden er værst for kvinder. Forestillinger om slægtskab og køn er tillige forbundet med en kulturspecifik tilblivelseshistorie, hvor kropslige og biolo- 
giske processer spiller en prominent symbolsk rolle, ikke mindst som kilde til ideer om autenticitet. At blive, hvad der forstås som rigtig far og rigtig mand, er afhængig af, at kroppen formår at være aktør og bidragyder i denne historie. Disse kriterier for autenticitet bliver særlig tydelige set fra de infertile mænds perspektiv. For her kan de ikke umiddelbart være med. De må omdefindere såvel deres faderskab som deres forestillinger om maskulinitet ved for eksempel at betone de sociale aspekter af faderskabet, herunder også nærhed til den gravide kvindekrop og deltagelse i graviditetsforberedelser og fødsel. Hvad angår det sidste, hjælpes de i nogen grad på vej af nye ideer og praksisser om faderskabets udfoldelsesradius. De infertile mænd må tillige forsøge at adskille en tætknyttet kulturel association mellem reproduktiv formåen, seksualitet og maskulinitet, der også, som vist, kobles til ideer om mænd som kropsligt intakte, uafhængige og som forsørgere. Infertilitet er for både mænd og kvinder forbundet med tab af kontrol, men meget tyder på, at kontroltabet er sværere for mænd at håndtere, end det er for kvinder.

I artiklen har jeg også vist, at de infertile og barnløse mænd og kvinder refererer til køn, som en måde at markere og give mening til specifikke erfaringer og praksisser på. Derved eksponeres kulturelle forestillinger om kønnenes væsen, og altså også specifikke maskuline træk. Det er for eksempel forestillinger om kvinder som åbne, emotionelle og særlig optaget af families trivsel og reproduktive emner og mænd som følelsesmæssigt lukkede, tavse, og initiativløse, når det vedrører de reproduktive aspekter af deres liv. Disse markeringer er i nogen grad produkter af, at kvindekroppen og moderskabet har været i centrum medicinsk, kulturelt og videnskabeligt og dermed skygget for viden om mænd, deres kroppe og deres reproduktive liv. Den stigende interesse for mænd signalerer heldigvis et nødvendigt vendepunkt her.
Men det er ikke kun forskelle mellem kønnene, der er på spil. Faderskaber og maskuliniteter skal forstås relationelt og kontekstuelt. Køn er et relationelt forhold - og en forskel, der gør en forskel. Men det er også en forskel, der medieres og måske til tider overskygges af andre mere relevante forskelle. Forestillinger om maskuliniteter udfolder sig under alle omstændigheder også i mænds relationer til andre mænd: "Rigtige mænd får Øko-tvillinger”, stod der på bagruden af en Citroën Berlingo (i øvrigt kåret som den ultimative familiebil), der holdt foran mig en dag. En sætning, der klart markerer forskelle mellem mænd og samtidig introducerer nye kriterier for autenticitet. Rigtige mænd laver ikke kun økologiske børn (som jeg forstår ordene, er det børn, der er lavet på almindelig vis, måske ovenikøbet forenet med forældrenes økologiske levevis), men de gør det i en slags "andenpotens". Her kan de infertile mænd slet ikke være med. Både mændene og de børn, de måske får med hjælp af forplantningsteknologien eller ved adoption må finde og insistere på andre kilder til autenticitet.

\section{NoTER:}

1. Enkelte af de undersøgelser, der beskæftiger sig med infertilitet, barnløshed og fertilitetsbehandling, inddrager og analyserer både mænds og kvinders erfaringer og peger på kønforskelle i håndteringen af infertilitet og barnløshed (fra Skandinavien se især Lundin 1997, Schmidt 1996, TjørnhøjThomsen 1999 og Wirtberg 1992).

2. Afhandlingen er baseret dels på et to-årigt feltarbejde i tre lokale grupper af Landsforeningen af ufrivilligt barnløse i Danmark, dels på dybdegående interviews med 22 barnløse par og enkeltpersoner. Besøg og deltager-observation på fertilitetsklinikker hører også til de benyttede dataindsamlingsmetoder.

3. Teknologien udviklingstendens er at sikre, at forældre kan blive genetisk forbundet med deres børn og er derved med til at reproducere og forstærke den kulturelle betydning af genetisk forbundethed mellem fædre og børn (cf. Dwight 1996). 
4. Konjugalitet er et begreb for relationen og den særlige forbundethed, der eksisterer mellem parterne i et ægteskab eller i et æateskabslignende forhold.

5. Der kan være mange årsager til barnløsheden (se Lundstrøm 1998). Ødelagte æggeledere er den hyppigste "kvindelige faktor" ofte forårsaget af underlivsbetændelse (Nyboe Andersen et. al 1996,36). Mens en, af flere mulige årsager og forskelligt omfang, nedsat sædkvalitet er den almindelige mandlige faktor.

6. "Infertilitet" og "ufrivillig barnløshed" er begreber, der ofte ligestilles, men der er behov for at skelne. Parrets ufrivillige barnløshed skyldes i mange tilfælde den ene af parternes infertilitet, som er en tilstand, der som regel refererer til det enkelte individ (selv om parret også sammen kan være infertile, uden at nogle af parterne er det hver for sig). De ufrivilligt barnløse, der har bidraget til min undersøgelse (cf. Tjørnhøj-Thomsen 1999), er alle heteroseksuelle par, hvorfor termen ufrivilligt barnløs er knyttet hertil. Infertile eller ufrivilligt barnløse enlige eller lesbiske har ikke adgang til kunstig befrugtning. I artiklen her bruger jeg "barnløs" som en fællesbetegnelse for infertil og ufrivillig barnløs. Det er en betegnelse, der altså ikke her omfatter dem, der har valgt en tilværelse uden børn.

7. Disse tanker om forholdet mellem narrativ og identitet og narrativt brud er inspireret af blandt andre Ricoeur (1991a,b) og Mattingly (1998). 8. Ingen barnløse (cf. Tjørnhøj-Thomsen 1999) mener dog, at deres tilstand kan sammenlignes med alvorlige, livstruende sygdomme.

9. Hvor vi i dag betoner faderens og moderens lige store genetiske bidrag, og altså en duo-gentisk forplantningsteori, så var det en monogenetisk forplantningsteori, der fandt udbredelse i Europa og USA helt frem til midten af det 20-århundrede; monogenetisk, fordi det kun var manden, der bidrog til genesen.

10. For en nøjere beskrivelse af, hvorledes teknologien griber ind i den almindelige tilblivelseshistorie se Tjørnhøj-Thomsen (1999), specielt kapitel 7. 11. Jeg refererer her især til den debat, der gik forud for vedtagelsen af "Loven om kunstig befrugtning", som blev vedtaget i 1997.

12. Se også Schmidt (1996) for forskelle mellem mænd og kvinder $\mathrm{i}$ deres håndtering $\mathrm{og}$ italesættelse af infertilitet og barnløshed

13. Der er interessante paralleller mellem de "identitesdilemmaer" (cf. Charmaz 1995), som mænd, der pludselig rammes af kronisk sygdom og invaliditet, oplever (ibid.) og dem, der artikuleres af de infertile mænd og deres partnere
14. Her udvælger laborant eller biolog den eller de sædceller, der er normale og injicere eller deponerer sædcellen i ægget med en tynd nål.

15. Jeg har ikke i min undersøgelse (TjørnhøjThomsen 1999) inddraget par, som har gjort brug af ægdonor. Der er meget få ægdonationer, blandt andet fordi det kun er kvinder, der er i IVF-behandling, der ifølge loven må donere æa. Nogle peger på, at det er nemmere for par at acceptere brug af donoræg, hvor kvinden føder og bærer barnet, og ingen af parterne derfor er uden for barnets tilblivelseshistorie (Nyboe Andersen et. al 1996,117). Diskussioner og overvejelser om at modtage (eller give) kønsceller tydeliggør under alle omstændigheder, at mænd og kvinder ikke er involveret i tilblivelseshistorien på samme måde.

\section{LITTERATUR}

. Becker, Gary (1994): "Metaphors in Disrupted Lives, Infertility and Cultural Constructions of Continuity", in Medical Anthropological Quarterly, vol. 8 (4): 456-471.

. Bergsten, Birgitta og Bäck-Wiklund, Margareta (1996): "Modern Fathers - Between Tradition and Relation", in Ulla Björnberg og Anna-Karin Kollind (eds.): Men's Family Relations. Report from an International Seminar, pp. 59-78, Almqvist \& Wiksell International, Göteborg. . Bourdieu, Pierre (1996): "On the Family as a Realized Category", in Theory, Culture \& Society, Vol. 13 (3): 19-26.

. Charmaz, Kathy (1995): "Indentity Dilemmas of Chronically Ill Men", in Donald Sabo og Davis Frederick Gordon (eds.): Men s Health and Illness. Gender, Power and the Body, pp. 266-291, Sage Pubclications, London.

. Dwight, Kirsten (1996): "Sperm Stories: Romantic, Entrepreneurial, and Environmental Narratives about Treating Male Infertility", in Science as Culture, vol. 6, part 2, no. 27: 246-276.

. Foucault, Michel (1980): The History of Sexuality, Volume 1, An introduction. Vintage Books Edition, New York.

. Franklin, Sarah (1997): Embodied Progress. A Cultural Account of Assisted Conception. Routledge, London.

. Gillis, John R. (1992): "Bringing Up Father. Britiske faderidentiteter fra 1750 til i dag", in Den Jyske Historiker, nr. 58-50: 149-176.

. Gillis, John R. (1996): A World of Their Own Making. Myth Ritual and the Quest for Family Values. Basic Books, New York. 
. Hagström, Charlotte (1996): "Pappablivande og faderskapande”, in Susanne Lundin og Lynn Åkesson (red.): Kroppens Tid. Om Samspelat mellen kropp, identitet och sambälle, pp. 57-89, Bökforlaget Natur och Kultur, Borås.

. Jagd, Christina Bakkelund (1998): Familien -Et Individualistisk Fallesskab. Specialeafhandling, Institut for Antropologi, København.

. Koch, Lene (1989): Ønskebørn. Kvinder \& Reagensglasbefrugtning. Rosinante, Charlottenlund.

. Leder, Drew (1990): The Absent Body. The University of Chicago Press, Chicago.

. Lundin, Susanne (1997): Guldägget. Föräldraskap i biomedicinens tid. Historiska Media, Lund. . Lundström, Peter (1998): Politikens Bog om Barnløshed. Politikens Forlag, København.

. Lupton, Deborah og Barcley, Lesley (1997): Constructing Fatherhood. Discourses and Experiences. Sage Publications, London.

. Mattingly, Cheryl (1998): Healing Dramas and Clinical Plots. The narrative structure of experience. Cambridge University Press, Cambridge.

. McKeown, Kieran; Ferguson, Harry; Rooney, Dermot (1998). Changing Fathers? Fatherhood and Family Life in Modern Ireland. Collins Press, Cork.

. Nyboe Andersen, Anders; Hornnes, Peter og Ziebe, Søren (1996): Klar Besked om Barnløshed. Aschehoug Dansk Forlag A/S, København.

. Olsen, Bente Marianne (1999): Nye Fedre på Orlov. En analyse af de konsmassige aspekter ved foraldreorlovsordninger. Ph.d.-afhandling, Sociologisk Institut, København.

. Ricoeur, Paul (1991a): "Life in Quest of Narrative", in David Wood (ed.): On Paul Ricoeur. Narrative and Interpretation, pp. 20-33, Routledge, London.

. Ricoeur, Paul (199lb): "Narrative Identity", in David Wood (ed.): On Paul Ricoeur. Narrative and Interpretation, pp. 188-199, Routledge, London.

. Rosenbeck, Bente (1987): Kvindekøn. Den moderne kvindeligheds historie 1880-1980. Gyldendal, København.

. Schmidt, Lone (1996): Psykosociale konsekvenser af infertilitet og behandling. Foreningen af Danske Lxgestuderendes Forlag, København.

. Simpson, Bob (1997): "Representations and representation of family. An analysis of divorce narratives", in Allison James, Jenny Hockey and Andrew Dawson (eds.): After Writing Culture. Epistemology and Praxis in Contemporary Anthropology, pp. 51-70, Routledge, London.

. Strathern, Marilyn (1993): "Introduction. A Question of Context”, in J. Edwards, S. Franklin,
E. Hirsch, F. Price og M. Strathern: Technologies of Procreation. Kinship in the age of assisted conception, pp. 1-19, Manchester University Press, Manchester.

. Tjørnhøj-Thomsen, Tine (1999): Tilblivelseshistorier. Barnloshed, slagtskab og forplantningsteknologi $i$ Danmark ph.d-række nr. 12, Institut for Antropologi, København.

. Wirtberg, Ingegerd (1992): His and Hers Childlessness, Department of Psychiatry and Psychology, Karolinska Instituttet, Stockholm.

\section{SUMMARY}

The article addresses the theme of "masculinities" from the perspective of infertile men and their partners. It argues that experiences of infertility should be understood as disruption in relation to the body and in relation to a narrative of life that is informed by cultural notions of kinship and gender. These notions are closely connected to a culturally specific story of coming-into-being, which gives symbolic priority to biological procreation and genetic connectedness. Being a real father and a real man depends on procreative abilities. In order to come to terms with infertility, infertile men try to redefine such ideologies of authenticity. The article illustrates how infertile men are confronted by strong cultural associations between fertility, sexuality and masculinity, and how these notions are related to other ideas of masculinity such as independence of the individual, ability to be a provider and a conception of the "intact" body. Finally, the article demonstrates how men and women differ in coping with infertility, childlessness and fertility treatment, and in their longings for parenthood. However, gender is not the only difference, which makes a difference in the world of infertile and childless people. The ideas of masculinities unfold through men's relations with other men and through generational differences and similarities.

Tine Tjørnhøj-Thomsen, ph. d. Institut for Antropologi, Københavns Universitet 